\title{
Die Ou Testament en/in die kerk van Jesus Christus? ${ }^{1}$
}

S D Snyman

(Universiteit van die Vrystaat)

\section{ABSTRACT}

\section{The Old Testament and/in the Church of Jesus Christ?}

The question raised in this contribution is suggested in the title: Should the place of the Old Testament be regarded as outside of, over against and thus not really part of the church or should the Old Testament be regarded as in the church as part of the canon of scriptures together with the New Testament. A historical overview is given to illustrate a movement in the interpretation of the Old Testament that started initially as a christological interpretation but developed in a more theological appreciation of the Old Testament. It is further indicated that the emphasis in both the exegesis and theology of the Old Testament is on the Old Testament's own theological integrity. Therefore there is no pressing need for a christological interpretation of the Old Testament as if that would be the one and only valid way of reading the Old Testament.

\section{INLEIDING EN VRAAGSTELLING}

Die vraag wat hier (nog eens) gestel word is die vraag na die plek en funksie van die Ou Testament in die kerk van Jesus Christus. Die vraag word ook anders geformuleer as byvoorbeeld die vraagstuk van Christus in die Ou Testament; of ' $n$ christologiese interpretasie van die Ou Testament; of die prediking van die Ou Testament in die kerk, of die verhouding tussen Ou en Nuwe Testament maar wesenlik gaan dit oor die plek en funksie van die Ou Testament in die kerk van Jesus Christus. Die vraagstuk van die verhouding tussen Ou en Nuwe Testament of die plek en funksie van die Ou Testament in die kerk en met name in die prediking is ' $\mathrm{n}$ vraag waaroor daar altyd diskussie is (Riekert 2004:67-79; van Rooy 2005:615-630). Die ambivalente titel van die artikel suggereer iets van die blywende ongemak met die plek van die Ou Testament in die kerk. Staan die Ou Testament teenoor die kerk (Die Ou Testament en die kerk van Jesus Christus) as die noodsaaklike, maar lastige en eintlik

1 Verwerkte en uitgebreide weergawe van ' $\mathrm{n}$ voordrag wat gelewer is voor studente van die Fakulteit Teologie aan die Universiteit van die Vrystaat, 24 Oktober 2006. 
agterhaalde voorloper tot die kerk? Of, vind die Ou Testament sy plek in die kerk (Die Ou Testament in die kerk van Jesus Christus) as deel van die korpus van kanoniese geskrifte saam met en gelykwaardig aan die Nuwe Testament?

\section{DIE OU TESTAMENT GEÏNTERPRETEER MET DIE OOG OP CHRISTUS}

Vir baie lank in die geskiedenis van die kerk is die plek wat die $\mathrm{Ou}$ Testament inneem in die kerk gedefinieer in terme van Christus. Volgens von Rad (1975a:319) is dit ongetwyfeld so dat die Ou Testament deur Jesus Christus, die apostels en die vroeë kerk gesien is as ' $n$ versameling van voorspellings wat na Hom (Jesus) gewys het as die redder van Israel en die wêreld. Die waarde van die Ou Testament het gelê in die mate waarin die Ou Testament in verband gebring is en kon word met Christus. Dat dit gebeur het, is te begrype. Die Ou Testament was immers die Bybel van die vroeë kerk. Israel se Bybel (dit is: die Ou Testament) was van die begin af die Heilige Skrif vir Christelike gemeenskap (Anderson 1999:7-8; Rendtorff 2005:749,752). Die Christus-gebeure (die koms, woorde, dade, kruisiging, opstanding en hemelvaart van Jesus Christus) is geïnterpreteer in terme van die Ou Testament. Die Ou Testament se taal en begrippe, kortom die teologiese woordeskat van die $\mathrm{Ou}$ Testament, is gebruik om die ingrypende en omvattende betekenis van die Christus-gebeure mee te beskryf en ook te interpreteer. Niemand minder nie as Jesus haal volgens die Evangelies die Ou Testament gesaghebbend en instemmend aan. Navorsing toon dat die Nuwe Testament die Ou Testament meer as 350 keer direk aanhaal (Ausloos \& Lemmelijn 2005:89). Die Nuwe Testament is vol van aanhalings en toespelings op die Ou Testament. Greidanus (1999:185) wys daarop dat navorsing wat hieroor gedoen is toon dat daar 1604 aanhalings in die Nuwe Testament is van 1267 OuTestamentiese passasies. 229 van die 260 hoofstukke waaruit die Nuwe Testament bestaan bevat ten minste twee aanhalings of verwysings na die Ou Testament. In die (sogenaamde egte) briewe van Paulus aan die Romeine, Korintiërs, Galasiërs, Filippense, I Tessalonisense en Filemon is daar 90 aanhalings uit die $\mathrm{Ou}$ Testament (Schreiner 1999:80). Daar word bereken dat 32\% van die Nuwe Testament bestaan uit aanhalings van en toespelings op die $\mathrm{Ou}$ Testament (Greidanus 1999:185). Die God wat Hom in die Ou Testament openbaar het, is dieselfde God wat Hom in Jesus Christus openbaar en as sodanig is die Ou Testament die noodsaaklike 
voorwaarde vir die verstaan van die Nuwe Testament se boodskap aangaande Jesus van Nasaret.

So ontstaan daar ' $n$ tradisie van interpretasie in die kerk: die $\mathrm{Ou}$ Testament moet christologies verstaan en ontsluit word. Die waarde van die Ou Testament lê in sy talle heenwysings na en voorspellings van die Messias-Christus wat sou kom. Luther se hermeneutiek kan opgesom word met die beroemde aanhaling van Luther dat die teks gevra moet word "ob sie Christum treyben odder nit” (Frör 1968:118) wat, vry vertaal, weergegee kan word met die vraag: bring die teks Christus na vore of nie? Toegepas op die Ou Testament beteken dit noodwendig ' $n$ christologiese interpretasie van die Ou Testament mee. Die direkte betrekking wat die OuTestamentiese teks het op Jesus Christus, sy lewe en woord, dood en opstanding, sy kerk en sy werk aan gelowiges is deurgaans die sterkste en omvattendste motief in Luther se uitleg van die $\mathrm{Ou}$ Testament is Bornkamm (Frör 1968:118) se bevinding in sy studie oor Luther en die Ou Testament. Die Pauliniese teenstelling tussen wet en evangelie is egter ook vir Luther 'n sleutelbegrip in die uitleg van die Ou Testament.

In die loop van die geskiedenis het daar verskillende modelle ontstaan om die verhouding tussen die twee Testamente mee te beskryf. Dit is opvallend dat daar ten spyte van die algemene konsensus dat die Ou Testament in terme van Christus verstaan en verklaar moet word, daar nooit net een model van interpretasie was nie. Modelle soos allegorie, tipologie, wet: evangelie, belofte: vervulling, kontinuïteit:diskontinuïteit is en was in die loop van die geskiedenis van interpretasie van die Ou Testament prominent om die verhouding tussen $\mathrm{Ou}$ en Nuwe Testament mee te verduidelik (Bright 1977, Gunneweg 1978, Preuss 1984, Greidanus 1999, Snyman 2002:126-146, Riekert 2004:67-79). Die groot aantal modelle weerspieël egter ook iets van die ongemak waarmee die verhouding tussen die Testamente beleef is. Geen model kon werklik reg laat geskied aan die probleem van die verhouding tussen $\mathrm{Ou}$ en Nuwe Testament nie.

Die slagoffer van die ontoereikende modelle was die $\mathrm{Ou}$ Testament. Teen wil en dank moes die Ou Testament op 'n manier christologies verklaar word. Immers, so het die argument gelui, ' $n$ verklaring of preek uit die Ou Testament wat nie "by Christus uitkom nie", kan net so wel in 'n sinagoge gepreek word. Geen 
wonder nie dat ' $\mathrm{n}$ bekende Ou-Testamentikus soos prof P A Verhoef gewaarsku het teen ' $\mathrm{n}$ voortydige christologiese verklaring van die Ou Testament (Verhoef 1977:151).

Hoe goed bedoel ook al, nie een van die bekende hermeneutiese sleutels laat reg geskied aan die Ou Testament as Woord van God nie. Die Ou Testament word met die modelle gereduseer tot voorlopige Woord van God. Telkens kry die Ou Testament eers ("sy ware") betekenis in die lig van die Nuwe Testament op so 'n manier dat die eiendomlike en unieke seggingskrag van die (teks van die) Ou Testament eintlik verlore gaan. Die boodskap van die Ou Testament het net waarde in soverre as wat dit 'n eggo is van wat klaar in die Nuwe Testament staan. Tereg merk Le Roux (1999:107) op: “Terme soos belofte-vervulling, wet-evangelie, voorlopig-volledig, tydelik-permanent, ensovoorts pas óf nie meer nie óf dit moet afgeskaal word. Sulke begrippe is ' $n$ enorme verskraling van die Ou-Testamentiese werklikheid. Sulke terme het die Ou Testament oor die eeue tot ' $n$ antieke boek verding”. Brueggemann (1997:730) maak 'n soortgelyke opmerking: “...none of these rubrics (belofte-vervulling, wet-evangelie, heilsgeskiedenis, typology - SDS) nor all of them together catch what is decisive in the Old Testament for the New Testament and for Christian faith". Die boodskap van die Ou Testament mag nie opgelos word in die Nuwe Testament nie. Die Ou Testament mag nie gedegradeer word tot ' $\mathrm{n}$ tweede klas kanon waardeur die stem van die Ou Testament tot stilte gesnoer word nie. Dit is 'n verskraling van die $\mathrm{Ou}$ Testament wanneer die Nuwe Testament die "kontrolepunt" vir die Ou Testament word.

Die Ou Testament is net te ryk, te gevarieerd, te omvattend om deur ' $n$ enkele keurslyf gelees en geïnterpreteer te word. Dit bring ' $n$ dramatiese verskraling van die Ou Testament te weeg, want wat maak ' $n$ mens met tekste wat hulle nie leen tot ' $n$ christologiese ontsluiting nie? Te dikwels gebeur dit dat sulke tekste eintlik net geïgnoreer word tot skade van die kerk en gelowiges want daardeur word die openbaring van God vereng.

\section{DIE TEOLOGIESE EIEWAARDE VAN DIE OU TESTAMENT}

Teenoor die interpretasie van die Ou Testament alleen met die oog op Christus, is daar ook ' $n$ ander moontlikheid, die moontlikheid van die teologiese eiewaarde van die Ou Testament. 


\subsection{Historiese voëlvlug}

Die Hervorming van die sestiende eeu bring ' $n$ nuwe aksent in die verstaan van die Bybel. Waar die Bybel gesien is as ' $\mathrm{n}$ onuitputlike bron van proeftekste (die sg dicta probantia) wat die dogmatiese leerstellings van die kerk van ' $n$ Bybelse basis moes voorsien, het daar ook onder die invloed van die reformatoriese slagspreuk van "sola scriptura" "n eksegetiese tradisie ontstaan wat eers as die grammaties-historiese metode bekend was, maar later ontwikkel het tot die bekende histories-kritiese metode van Skrifuitleg. Teenoor ' $n$ meervoudige Skrifsin wat neerkom op verskillende betekenisvlakke, beklemtoon die reformatore die letterlike en historiese (sensus literalis sive historicus) betekenis van tekste. Dit beteken konkreet: "Die unter dem Prinzip "sola scriptura" enstandene Schriftforschung ist allein auf den sensus literalis sive historicus auszurichten” (Kraus 1982:10).

Die Bybel is hoe langer hoe meer verklaar met ' $\mathrm{n}$ groeiende sensitiwiteit vir die historiese bedding van tekste. Bybeltekste is dus nie kontekslose uitsprake wat a-histories en eklekties na willekeur saamgevoeg kan word om dogmatiese leerstukke te vorm of te ondersteun nie. Bybeltekste moet eerder verstaan word vanuit die historiese milieu en agtergrond waarin dit die eerste keer uitgespreek of op skrif gestel is (Snyman 2000:78-82).

Klassiek histories-kritiese eksegese beskou die Bybelse teks primêr as ' $\mathrm{n}$ historiese dokument. Daar is veral twee vrae aan die teks gevra: hoe het die teks ontstaan en wat is die historiese gehalte van die teks (Ausloos \& Lemmelijn 2005:77-78)? Pas wanneer die vrae geantwoord is, kon daar teologiese gevolgtrekkings gemaak word. Hierdie metode van Skrifuitleg het enorme implikasies vir die verstaan van die Bybel. Bybelse tekste is as ' $n$ histories gesitueerde tekste verstaan. So byvoorbeeld is raakgesien dat groot dele van Jesaja 1-39 uit die 8ste eeu vC kom, maar dat Jesaja 40-55 eers uit die 6de eeu dateer en dat Jesaja 56-66 heel waarskynlik ' $n$ naeksiliese geskrif is. Hierdie sensitiwiteit vir die historiese omstandighede waarbinne teks ontstaan het, het ook die manier waarop die verhouding tussen Ou en Nuwe Testament verstaan is, verander. As Nuwe Testamentiese tekste teologiese lyne na die Ou Testament trek, analogieë tussen die Nuwe en Ou Testament raaksien en die Ou-Testamentiese tekste dan christologies interpreteer, maak 
dit nie van daardie Ou-Testamentiese tekste voorspellings en heenwysings na Christus toe nie.

Die aandag het egter nie net by ' $n$ puur historiese interesse gebly nie. Saam met die historiese belangstelling was daar ook ' $n$ belangstelling in die literêre aard en gehalte van Bybelse tekste. Die komposisie en literêre genre van die teks kry al hoe meer aandag. Kortom, die aandag skuif van ' $n$ histories-literêre aanpak na ' $n$ literêr-historiese aanpak toe.

In die onlangse verlede - sedert ongeveer 1970 - het die klem nogeens verskuif vanaf die veronderstelde voorstadia van teksontwikkeling na ' $n$ fokus op die finale gestalte van die teks. Naas diakroniese (histories-kritiese) ondersoeke is daar ' $n$ groeiende beweging na sinkroniese (literêre) ondersoeke waar die Endgestalt van die teks ernstig geneem word (Snyman 2000:82-83). Saam met die ontwikkeling is daar ook ' $n$ groeiende beklemtoning van die teologiese boodskap van die teks teenoor ' $n$ histories-kritiese benadering wat dikwels die betekenis van die teks in die verlede laat "stol" het.

In die hedendaagse diskussie word beide die historiese en literêre dimensies van die teks ernstig opgeneem (De Moor 1995, Utzschneider \& Nitsche 2001, Talstra 2002:108-111, Jonker 2006:58-76). Die historiese konteks waarbinne ' $n$ teks ontstaan het, is onontbeerlik vir die verstaan van die teks. Eweneens lewer ' $n$ literêre ondersoek van die teks ook waardevolle resultate. Trouens, die meeste hedendaagse eksegetiese modelle is " $n$ kombinasie van literêre en historiese dimensies van die teks. Die resultate van so ' $n$ ondersoek lewer dan die boustene van die teologiese boodskap of teologiese intensie van die teks.

Hierdie insigte het meegebring dat talle tekste wat tradisioneel christologies of messiaans verklaar is, nie meer so verklaar word nie omdat die literêre en historiese dimensies van eksegetiese ondersoek dit gewoon so uitgewys het. Die tendens is eerder om die OuTestamentiese teks te lees en te waardeer vir sy eie teologiese boodskap wat ook waarde het vir die kerk van Jesus Christus omdat die Ou Testament deel is van die kanon van die kerk. 


\subsection{Ontdekking van en waardering vir die teologiese eiewaarde van die Ou Testament}

Die ontdekking op grond van eksegetiese resultate dat baie tekste wat gemeen is voorspellings of heenwysings of profesieë van Christus is en dit toe nie is nie, het nie ' $n$ lugleegte van betekenis tot gevolg gehad nie, maar het eerder die teologiese eiewaarde van die Ou Testament na vore laat kom. Die posisie van die Ou Testament in die Christelike kanon wys alreeds in die rigting. In die kanon staan die Ou Testament voor die Nuwe Testament. Die plasing van die Ou Testament en die Nuwe Testament wys nie net na die histories en teologies kontinue lyn van God se openbaring nie, maar ook na die eie en selfstandige plek van die Ou Testament. Sou die Ou Testament na die Nuwe Testament geplaas word in gedrukte weergawes van die Bybel, sou dit beteken dat die Ou Testament hoogstens ' $n$ nuttige verwysingsbron vir die Nuwe Testament sou wees. Dit is verder opvallend dat die vroeë kerk nie die teks van die Ou Testament verchristelik het nie, maar dat die teks sy eie outentieke gestalte bly behou het. Geen redaksionele veranderings is gemaak om die $\mathrm{Ou}$ Testament meer Christelik te maak nie. Daar is ook geen Christelike kommentaar bygevoeg by Ou-Testamentiese tekste nie wat vir Childs (1992:75-78) die bevestiging is van die voortdurende integriteit van die Ou Testament wat "op sy eie terme" gehoor moet word. In die tweede eeu word die aanslag van Marcion op die $\mathrm{Ou}$ Testament as kanon van die kerk, deur die kerk afgeweer met die gevolg dat die Ou Testament voluit deel is van die kanon. Die toenemende kontak tussen Ou-Testamentici vanuit die Christendom en hulle eweknieë uit die Joodse geloof het ook bygedra tot ' $n$ waardering vir die eie stem van die Ou Testament, immers vir die Joodse geloof is die Ou Testament kanon en nie net deel van die kanon soos in die Christendom nie.

Dit is nie net die eksegese van die Ou Testament wat algaande die eie en unieke boodskap van die Ou Testament na vore laat kom het nie, ontwikkelings op die gebied van die Teologie van die $\mathrm{Ou}$ Testament dui op dieselfde tendens. Barr (1999) gee ' $n$ veel meer omvattende oorsig oor die saak, maar wanneer die hoofmomente en metodologiese draaipunte en vernuwings in die Teologie van die $\mathrm{Ou}$ Testament nagaan word, is die tendens van ' $n$ groeinde besef van die teologiese eiewaarde van die Ou Testament onteenseglik daar. Barr (1999:255) maak byvoorbeeld die waarneming dat dit opvallend is dat tradisionele Christelike 'dogmas' soos die maagdelike geboorte, 
die drie-eenheid of die inkarnasie vermy word. Selfs die gedagte van ' $n$ messiaanse verwagting word selde in verband gebring met Jesus en sy lewe.

Waar die Teologie van die Ou Testament aanvanklik in tipies dogmatiese kategorieë (God - mens - redding oftewel teologie, Christologie, soteriologie) beskryf is, publiseer Eichrodt (1975 1933 1ste uitgawe) sy Teologie met die verbond - 'n tema tipies aan die Ou Testament - as sentrale tema. Die aanbieding van 'n Teologie van die Ou Testament sê Eichrodt (1975:32-33) mag nie kom van 'n dogmatiese skema nie, "we must avoid all schemes which derive from Christian dogmatics...Instead we must plot our course as best as we can along the lines of the Old Testament's own dialectic". Later publiseer von Rad (1975 - 1959 1ste uitgawe) sy Teologie van die $\mathrm{Ou}$ Testament wat die geskiedenis soos aangebied in die $\mathrm{Ou}$ Testament as uitgangspunt het en wat nogeens ' $n$ beweging na die Ou Testament is en weg van dogmatiese kategorieë. In die meer onlangse verlede is die Ou Testament Teologieë van Brueggemann (1997) wat ' $n$ hof-metafoor gebruik en Gerstenberger (2002) wat ' $n$ sosiologiese benadering volg, voorbeelde van ' $n$ aanpak weg van dogmatiese kategorieë. Childs, bekend vir sy kanoniese benadering tot die Ou Testament, het in sy Bybelse Teologie ' $n$ sterk saak uitgemaak vir wat hy noem die integriteit van beide die Ou en die Nuwe Testament (1992:77-78). Die klem moet val op die eenheid van die een komposisie wat bestaan uit twee testamente. Die versoeking moet weerstaan word om Bybelse Teologie te identifiseer met die Nuwe Testament se interpretasie van die Ou Testament asof die Ou Testament se getuienis beperk is tot hoe dit een keer gehoor en geïnternaliseer is deur die vroeë kerk. So ' $n$ benadering vernietig die teologiese integriteit van die Ou Testament en mak sy ware kanoniese getuienis stil (Childs 1992:77). In sy vroeëre Teologie van die Ou Testament waarsku Childs teen ' $\mathrm{n}$ verchristeliking van die $\mathrm{Ou}$ Testament. Die taak van die Teologie van die Ou Testament is om te luister na die eie teologiese getuienis van die Ou Testament aangaande die God van Israel, die God wat ook in die kerk aanbid word (Childs 1985:9).

' $n$ Oorsig oor die jongste literatuur weerspieël hierdie nuwe waardering van die Ou Testament as teologiese dokument.

- $\quad$ Anderson (1999:9-12) praat van die relatiewe onafhanklikheid van die Ou Testament. Een van die implikasies van die 
beskouing van Anderson is dat: "we are obligated to let the Old Testament speak with its own voice, even though that means interpreting passages differently than New Testament authors do" (Anderson 1999:10).

Hy gaan voort: "Of course, in the Christian community it is proper to regard Scripture as a whole in a christological perspective, but this does not mean forcing particular texts to bear witness to Jesus Christ or to carry a Christian meaning” (Anderson 1999:11).

- Van Rooy (2005:622) se standpunt is: “Omdat die Ou Testament self aan die orde moet kom, moet in die eksegese en prediking by die Ou Testament in sy oorspronklike konteks begin word. Dit is nie geregverdig om Christus of ' $n$ Christelike betekenis in die Ou Testament in te lees vanuit die Nuwe Testament nie".

- $\quad$ Brueggemann (1997:731) maak byvoorbeeld die opmerking dat dit duidelik is "that the Old Testament does not obviously, cleanly or directly point to Jesus or to the New Testament...As a Christian interpreter, I think we would do better to acknowledge the independent status of the Old Testament text and then to move toward the New Testament...”.

- $\quad$ Birch en andere (1999:27) se standpunt in die verband kan met die volgende aanhaling weer gegee word: "Since for Christians the canon of scripture includes the books of the New Testament, there have been prominent modes of interpretation that seek to find some form of overt witness to Jesus Christ in the Old Testament. We do not believe that is ever the intent of the Hebrew text. Israel's witness to its experience with God posesses its own integrity, which does not allow us to identify specific texts as part of the church's Christology in their initial context”.

- In sy inleiding tot die Ou Testament skryf Brueggemann (2003:2): “The 'Old/New' connection seems to preempt completely the Old and to exclude any reading of it except a reading toward the New. While this is a long-established Christian assumption and practice, it is now not one that can be sustained...”. 
- Gerstenberger (2002:283) stel die saak so: "the Christian element in reading and understanding the Hebrew scriptures lies in our tradition and not in the Old Testament”.

- $\quad$ Heel onlangs is Rendtorff (2005:752) se mening dat ons nie die betekenis van die Ou Testament vir die Christelike kerk peil of beoordeel vanuit die Nuwe Testament of van die teologie daarin vervat nie. Die Ou Testament is nie geabsorbeer in die Nuwe Testament om daardeur sy eie waardigheid te verloor nie. God se laaste kommunikasie (in Jesus Christus) maak nie sy verskillende en vorige kommunikasies oorbodig of betekenisloos nie (Rendtorff 2005:754).

Toenemend is en word die Ou Testament gelees vir sy eie en selfs unieke teologiese boodskap. Meer en meer word die Ou Testament gesien as die neerslag van (gelowige) mense se ontmoeting, ervaring, belewenis van God (in sy openbaring aan hulle). Daardie neerslag is God se openbaring aan ons. Mense se verwondering oor God het oorgegaan in ' $n$ verwoording in tekste wat gegroei tot versamelings en boeke en eventueel tot dit wat vandag bekend is as die Ou Testament. Die verwoording wek by ons as huidige lesers opnuut weer verwondering oor God wat Hom juis so openbaar in die Ou Testament. Wanneer die leser miskien ' $n$ prediker is, word die prediker-leser se verwondering ook weer verwoord in ' $n$ preek wat (hopelik!) die lidmate wat Sondag luister na die verwoording van sy/haar verwondering, ook met verwondering sal laat soos wat die eerste mense se ervaring of belewenis van God hulle met verwondering gelaat het.

\subsection{Deel van die kerklike praktyk}

Van nader beskou is die manier van hantering van die Ou Testament alreeds praktyk in die kerk. Berymde Psalms word gesing in eredienste sonder dat die liedere eers christologies geïnterpreteer word. Die Tien Gebooie word in eredienste gelees as die openbaring van God se wil vir gelowiges sonder dat die gebooie eers christologies geïnterpreteer word. Die votum word aan die begin van ' $n$ erediens uit Psalm 121 of Psalm 124 uitgespreek en die erediens word afgesluit met die Aäronitiese seën uit Numeri 6 sonder enige christologiese duiding. Psalm 23 en ook ander Psalms en dele van die $\mathrm{Ou}$ Testament word vrugbaar in die pastoraat gebruik om gelowiges te bemoedig of te vertroos sonder dat dit nodig is om die 
Skrifgedeeltes eers christologies te verduidelik. Psalm 103 word probleemloos gelees as lofverheffing na die viering van die Nagmaal sonder dat ' $n$ christologiese interpretasie nodig is.

Dit is verder opvallend dat die Heidelbergse Kategismus in die sy uitleg van die Tien Gebooie nie ' $n$ enkele keer die naam van Christus noem of die gebooie christologies probeer interpreteer nie. Luther het in sy Kategismus die Dekaloog aan die begin geplaas sonder enige Christelike regverdiging om dit so te doen. Vir Luther is die Dekaloog die "geliefd en gewaardeerd bo alle ander leringe as die hoogste skat wat deur God gegee is” (Rendtorff 2005:742).

\section{DIE RESULTAAT: 'N RUIMER, DIEPER, RYKER TEOLOGIESE INSIG VIR DIE KERK}

Die waarde wat die tendens vir die verstaan en waardering vir die plek van die Ou Testament in die kerk het, moet positief waardeer word. Om na die eie stem van die Ou Testament te luister, is verrykend en selfs ook verrassend. Tekste wat nie christologies gedui kon word nie en wat dus prakties geïgnoreer is, kan nou nuut gehoor word.

Is dit dan verkeerd of teologies ontoelaatbaar om die $\mathrm{Ou}$ Testament nog steeds christologies te interpreteer? Die Ou Testament word lank nie meer op net een manier geïnterpreteer nie. Talstra (2002:109) merk op: "Studies van exegetische methoden vertonen de neiging de diversiteit aan methoden als een gegeven te accepteren door de verschillende methoden eenvoudig naast elkaar te plaatsen”. Bo en behalwe die meer gebruiklike lees van die Ou Testament as (oorwegend) histories en/of (oorwegend) literêr is daar ook feministiese, bevrydingsteologiese, swart teologiese, materialistiese, Marxistiese, politieke, psigologiese, ekologiese, kanon kritiese en waarskynlik nog ' $\mathrm{n}$ reeks ander lesings moontlik (Botha et al 1994:63-202; Jonker \& Lawrie 2005:171-228). Die Ou Testament mag dus nog steeds christologies en/of messiaans geïnterpreteer word. Dit is deel van ' $n$ lang tradisie van uitleg in die kerk wat as sodanig behou kan word. Trouens, om die Ou Testament te interpreteer in terme van Christus soos wat die vroeë kerk gedoen het, was ' $n$ verbeeldingryke en kreatiewe onderneming wat waardeer moet word. In baie gevalle is daar geen spanning tussen Ou en Nuwe Testament nie en word die teologiese boodskap van die een Testament gewoon gekontinueer in die ander. Dit is egter ' $n$ verskraling van die ryk boodskap van die Ou Testament om dit net in 
terme van Christus te interpreteer. Die inhoud van die Ou Testament is meer as net christologiese heenwysings na Christus toe.

Daar is dus ' $\mathrm{n}$ keuse vir die hedendaagse interpreteerder van Ou Testamentiese tekste. Aan die een kant kan die interpreteerder volhard met die lang en gerespekteerde tradisie van ' $n$ christologiese uitleg van die $\mathrm{Ou}$ Testament en telkens tot 'n christologiese konklusie kom as resultaat van sy/haar eksegeties-teologiese besigwees met die teks. Die Ou Testament hoef nie net christologies geïnterpreteer word in die kerk nie. Aan die ander kant kan die interpreteerder die teologiese seggingskrag van die teks ernstig opneem en kies om eerder die teologiese boodskap as resultaat van eksegese te kommunikeer. Die tweede (en verkieslike) keuse beteken nie ' $n$ Christuslose prediking van Ou Testament tekste nie. Die volgende aanhaling van Gerstenberger (2002:283-284) is hier van toepassing: "Today we live on the foundations of the Hebrew Bible, but with all kinds of superstructures and constructs from the GraecoRoman world. That is how our Christian or post-Christian starting point has to be described. And it is from this standpoint that we approach the Hebrew theologies of the Old Testament. So we do not need first to incorporate a Christian filter into our reading of the Old Testament. It is already there in ourselves and in our tradition, in our perception and interpretation". Christen-uitleggers van die Ou Testament kan hulleself nie verplaas asof in ' $n$ tyd-masjien na ' $n$ periode van voor Christus nie. Uitleg en verklaring van die Ou Testament vind dus plaas nie met die oog op Christus nie, maar eerder vanuit Christus of soos wat Birch ea (1999:19) dit stel: "we cannot escape the particularity of our exposition of the Biblical text as Christian interpreters”. Immers, mag die voortgaande interpretasie van die Bybelse teks hom ooit laat konformeer of beperk tot die grense en eise van kerklike tradisies, oortuigings en geloof (Brueggemann 2003:xii)?

\section{SLOT}

Hoe sou die plek van die Ou Testament in terme van die kerk van Jesus Christus beskryf word? Word die verhouding tussen Ou Testament en kerk die beste beskryf deur "en" of "in" die kerk? Die argument wat in hierdie bydra gevoer is, argumenteer ten gunste van 'n standpunt van die Ou Testament in die kerk waar dit saam met die Nuwe Testament as kanon geag, gelees gewaardeer en geïnterpreteer word. Indien hierdie opsie gevolg sou word, sou dit enorme 
implikasies vir ander teologiese dissiplines soos dogmatiek en die verskillende dissiplines binne die Praktiese Teologie hê. Die inhoud van handboeke in die dogmatiek kan anders lyk met 'n uitgangspunt wat die teologiese eiewaarde van die Ou Testament ernstig opneem. Insigte in die pastoraat kan verruim word met ' $n$ vars en nuwe waardering vir die Ou Testament. Homiletiek handboeke sal herskryf moet word om studente te leer om die Ou Testament anders te waardeer as wat tot dusver die geval was. Of het die selfstandigheid van die verskillende dissiplines so ver gevorder dat ontwikkelings binne die Bibliologiese dissiplines nie meer gehoor word of effek het op die ander teologiese dissiplines nie?

\section{Literatuurverwysings}

Anderson, B W 1999. Contours of Old Testament Theology. Minneapolis: Fortress.

Ausloos, H \& Lemmelijn, B 2005. De Bijbel: een (g)oude(n) gids. Bijbelse antwoorden op menslijke vragen. Leuven: Uitgeverij Acco.

Baker, D L 1992. Two Testaments, One Bible. A Study of the Theological Relationship between the Old \& New Testaments. Downers Grove: InterVarsity Press (Revised Edition).

Barr, J 1999. The Concept of Biblical Theology. An Old Testament Perspective. Minneapolis: Fortress.

Birch, B C, Brueggemann, W, Fretheim, T E \& Petersen, D L 1999. A Theological Introduction to the Old Testament. Nashville: Abingdon Press.

Botha, P J Bosman, H L Burden, J J \& Olivier, J P J (eds) 1994. Understanding the Old Testament in South Africa. Old Testament Essays 7(4) (Special edition), 63-202.

Brueggemann, W 1997. Old Testament Theology. Testimony, Dispute, Advocacy. Minneapolis: Fortress Press.

-, W 2003. An Introduction to the Old Testament. The canon and Christian Imagination. Louisville, Kentucky: Westminster John Knox Press.

Bright, J 1977. The Authority of the Old Testament. Grand Rapids: Baker Book House.

Childs, B S 1985. Old Testament Theology in a Canonical context. London: SCM.

-, 1992. Biblical Theology of the Old and New Testaments. Theological Reflection on the Christian Bible. London: SCM Press.

De Moor J C (ed) 1995. Synchronic or diachronic - A debate on method in Old Testament Exegesis. Leiden: Brill.

Eichrodt, W 1975. Theology of the Old Testament. London: SCM. 
Frör, K 1968. Wege zur Schriftauslegung. Biblische Hermeneutik für Unterricht und Predigt. Düsseldorf: Patmos (Dritte überarbeitete Auflage).

Gerstenberger, E S 2002. Theologies of the Old Testament. Edinburgh: T \& T Clark.

Greidanus, S 1999. Preaching Christ from the Old Testament. A Contemporary Hermeneutical Method. Grand Rapids: Eerdmans.

Gunneweg, A H J 1978. Understanding the Old Testament. London: SCM.

Kraus, H-J 1982. Geshichte der historisch-kritischen Erforschung des Alten Testaments. 3. Erweiterte Auflage. Neukirchen-Vluyn: Neukirchener Verlag.

Jonker, L \& Lawrie, D 2005. Fishing for Jonah (anew). Various approaches to Bibliacal Interpretation. Stellenbosch: Sun Press (Study Guides in Religion and Theology 7. Publications of the University of the Western Cape).

Jonker, L 2006. Reading with one eye closed? Or: What you miss when you do not read Biblical Texts Multidimensionally. Old Testament Essays 19(1), 5876.

Le Roux, J 1999. Hoe eindig die Ou Testament? (of: het die Ou Testament die Nuwe Testament nodig?) NGTT 40(1\&2), 100-109.

Preuss, H D 1984. Das Alte Testament in Christlicher Predigt. Stuttgart: Kohlhammer.

Rendtorff, R 2005. The Canonical Hebrew Bible. A Theology of the Old Testament. Leiden: Deo Publishing.

Riekert, S J P K 2004. Voorveronderstellings in die hantering van die verhouding tussen Ou en Nuwe Testament. 'n Beskrywing na aanleiding van Friedrich Baumgärtel, in Tolmie, D F (red) Die Woord verwoord. Artikels oor die Teologie. Eeufeesviering: Universiteit van die Vrystaat. Acta Theologica Supplementum 6, 67-79.

Schreiner, J 1999. Das Alte Testament verstehen. Würzburg: Echter Verlag (Neue Echter Bibel 4).

Snyman, S D 2000. Die eksegese van die Ou Testament - terugblik en vooruitskouing. Kaleisdoskoop 2000. Artikels oor Teologie. Acta Theologica Supplementum 1, 76-93.

-, 2002. Die verstaan en funksie van die Ou Testament in die kerk (of: kan die kerk klaarkom sonder die Ou Testament?) Deel I. Acta Theologica 22(2), 126-146.

Talstra, E 2002. Oude en Nieuwe Lesers. Een inleiding in de methoden van uitleg van het Oude Testament. Kampen: Kok.

Utzschneider, H \& Nitsche S A 2001. Arbeitsbuch literaturwissenschaftliche Bibelauslegung: eine Methodenlehre zur Exegese des Alten Testaments. Gütersloh: Güterloher Verlagshaus.

Van Rooy, H F 2005. Messiasverwagting en die prediking uit die Ou Testament. In die Skriflig 39(3), 615-630. 
Verhoef, P A 1977. Die weg en brug tussen Ou Testamentiese teks en prediking. NGTT 18(2), 145-157.

Von Rad, G 1975. Old Testament Theology Vol I. London: SCM.

-, 1975. Old Testament Theology Vol II. London: SCM. 